\title{
Peran kecerdasan emosi terhadap kepuasan pernikahan pada remaja yang menikah muda di Bali
}

\author{
Ni Luh Ari Pradnyadewi Asak dan Ni Made Ari Wilani \\ Program Studi Sarjana Psikologi, Fakultas Kedokteran, Universitas Udayana \\ ariwilani@unud.ac.id
}

\begin{abstract}
Abstrak
Dalam 10 tahun terakhir, menikah dilakukan pada usia yang lebih muda yakni remaja. Berdasarkan hasil survei sosial dan ekonomi nasional tahun 2012, Bali menempati peringkat 19 dalam prevalensi pernikahan remaja. Selain banyaknya pernikahan, data lainnya menunjukkan bahwa terdapat banyak kasus perceraian yang dilakukan oleh pasangan remaja. Kasus perceraian meningkat 10 persen setiap tahunnya di Bali, tepatnya di Kota Denpasar. Perceraian disebabkan oleh ketidakcocokan yang menjadi indikasi ketidakpuasan pada pernikahan. Salah satu aspek yang memengaruhi kepuasan pernikahan adalah kecerdasan emosi. Kecerdasan emosi merupakan hal yang harus dimiliki untuk menjaga kelangsungan pernikahan, terutama di usia muda. Berdasarkan pemaparan tersebut, tujuan penelitian ini adalah untuk mengetahui peran kecerdasan emosi terhadap kepuasan pernikahan pada remaja yang menikah muda di Bali. Penelitian ini menggunakan metode kuantitatif dengan subjek sejumlah 66 remaja usia 16-22 tahun yang telah menikah dan berdomisili di Bali. Subjek dipilih dengan menggunakan teknik probability sampling yaitu cluster area. Daerah yang digunakan dalam penelitian ini yakni Kota Denpasar, Kabupaten Gianyar, Kabupaten Bangli, Kabupaten Klungkung, Kabupaten Tabanan. Instrumen penelitian ini menggunakkan dua skala, yaitu skala Kecerdasan Emosi dan skala Kepuasan Pernikahan. Metode analisis menggunakan regresi linear sederhana dengan hasil $(\mathrm{t}=7,334 ; \mathrm{p}=0,000)$, sehingga dapat disimpulkan bahwa kecerdasan emosi dapat meramalkan kepuasan pernikahan pada remaja yang menikah muda di Bali. Nilai $\mathrm{R}$ sebesar 0,676 dan R square sebesar 0,457 yang berarti varian kecerdasan emosi dapat menjelaskan sebesar 45,7\% taraf varian kepuasan pernikahan.
\end{abstract}

Kata kunci: Kecerdasan emosi, kepuasan pernikahan, pernikahan muda.

\begin{abstract}
In the last 10 years, marriages were held at a younger age, namely teenagers. Based on the results of the national social and economic survey 2012, Bali is ranked 19th in the prevalence of adolescent marriage. In addition to the number of marriages, other data indicate that there are many cases of divorce committed by teenage couples. Divorce cases increase 10 percent every year in Bali, precisely in Denpasar City. Divorce is caused by differences that show dissatisfaction with marriage. One aspect that affects marital satisfaction is emotional intelligence. Emotional intelligence is a must-have for retaining marriage, especially at a young age. Based on the exposure, the purpose of this study was to determine the role of emotional intelligence on marital satisfaction in young married teenagers in Bali. In addition. This study uses quantitative methods with 66 subjects aged 16-22 years who have been married and domiciled in Bali. Subject chosen by using probability sampling technique that is cluster area. The area used in this research is Denpasar City, Gianyar Regency, Bangli Regency, Klungkung Regency, Tabanan Regency. There were two scale research instruments, namely Emotional Intelligence scale and Marital Satisfaction scale. The method of analysis using simple linear regression with the result $(t=7,334 ; p=0,000)$, so it can be concluded that emotional intelligence can predict marriage satisfaction in young married adolescents in Bali. $\mathrm{R}$ value of 0.676 and $\mathrm{R}$ square of 0.457 , which means the variant of emotional intelligence can explain $45.7 \%$ of the level of marital satisfaction variant.
\end{abstract}

Keywords: Emotional intelligence, marital satisfaction, young marriage. 


\section{LATAR BELAKANG}

Undang-undang No.1 Tahun 1974 di Indonesia menyatakan bahwa ketika usia laki-laki di atas 19 tahun dan perempuan di atas 16 tahun telah dianggap sah untuk melakukan pernikahan. Undang-undang pernikahan tersebut bertentangan dengan UU Perlindungan Anak Tahun 2002 yang menyatakan bahwa usia anak adalah di bawah 18 tahun maka orangtua bertanggung jawab untuk mencegah pernikahan usia anak (Badan Pusat Statistik [BPS], 2016). Usia minimal pada undang-undang pernikahan di Indonesia jika dilihat dari ilmu psikologi masih tergolong ke dalam tahap perkembangan remaja. Usia remaja yakni berawal dari usia 10-22 tahun (Santrock, 2007). Usia tersebut dikategorikan dalam usia muda untuk melakukan pernikahan.

Dewasa ini menikah dilakukan pada usia yang lebih muda yakni pada masa remaja (Badan Pusat Statistik [BPS], 2016). Masa remaja mempunyai arti yang lebih luas mencakup kematangan mental, emosional, sosial dan fisik (Hurlock, 2000). Remaja merupakan peralihan masa perkembangan antara masa kanakkanak ke masa dewasa yang meliputi perubahan besar pada aspek-aspek fisik, kognitif dan psikososial serta ditandai dengan munculnya pubertas (Papalia, 2009). Santrock (2007) menyebutkan bahwa masa remaja adalah periode transisi perkembangan antara masa kanak-kanak dengan masa dewasa yang melibatkan perubahan-perubahan biologis, kognitif dan sosio-emosional. Dalam tahap ini remaja tidak lagi merasa di bawah tingkat orang-orang yang lebih tua melainkan berada dalam tingkatan yang sama (Hurlock, 2000). Berdasarkan pengertian dalam Hurlock (2000) di atas maka dapat dikatakan bahwa remaja menikah untuk merasa setara dengan orang dewasa.

Hasil Survei Data Kependudukan Indonesia (SDKI) yang melakukan penelitian dengan sampel usia 15-19 tahun menemukan bahwa 17 persen perempuan usia 20-24 tahun pernah menikah sebelum berusia 18 tahun. Melalui data tersebut sebanyak 340.000 pernikahan di Indonesia terjadi pada perempuan berusia dibawah 18 tahun. Data Survei Sosial dan Ekonomi Nasional (Susenas) tahun 2012, menghasilkan angka 25 persen perempuan usia 20-24 tahun pernah menikah sebelum usia 18 tahun (Badan Pusat Statistik [BPS], 2016).

Dalam data Susenas pada tahun 2012 juga menjelaskan bahwa Bali mendapatkan peringkat 19 dalam prevalensi pernikahan remaja (Badan Pusat Statistik [BPS], 2016). Salah satu kabupaten di Bali yang turut menyumbangkan angka dalam hal ini adalah Tabanan. Tahun ajaran 2016/2017 terdapat 43 pelajar SMA/SMK di Tabanan yang putus sekolah. Kepala Sub Bagian Program dan Hukum Dinas Pendidikan Pemuda dan Olahraga Kabupaten Tabanan I Dewa Putu Kerta Wijaya mengatakan bahwa, pelajar SMA/SMK paling banyak putus sekolah dengan alasan menikah muda (Otonomi, 2016).

Dalam sebuah portal berita dalam jaringan (daring) yakni Balipost.com mengatakan bahwa Gianyar, Bangli dan Jembrana memiliki jumlah siswi SMA yang tinggi untuk menikah bahkan hingga memutuskan untuk tidak mengikuti ujian nasional. Di kabupaten Bangli terdapat 11 siswi SMA dan
SMK yang hamil memutuskan untuk menikah dan tidak mengikuti ujian nasional. Kabupaten Gianyar mencatat terdapat 4 siswi yang menikah dan tak mengikuti ujian nasional. Jembrana mencatatkan 2 orang siswi yang menikah ketika akan ujian nasional (Balipost, 2012).

Pernikahan adalah pintu bagi bertemunya dua hati dalam naungan pergaulan hidup yang berlangsung dalam jangka waktu yang lama, yang di dalamnya terdapat berbagai hak dan kewajiban yang harus dilaksanakan oleh masing-masing pihak untuk mendapatkan kehidupan yang layak, bahagia, harmonis, serta mendapat keturunan (Bachtiar, 2004). Menikah merupakan hal yang dilakukan manusia untuk memenuhi kebutuhan psikologis, kebutuhan seksual, kebutuhan material dan kebutuhan spiritual (Walgito, 2002). Menikah muda yang dimaksud dalam penelitian ini adalah pasangan yang menikah sesuai aturan Undang-undang pernikahan dan masih termasuk dalam tahap perkembangan remaja yakni remaja usia 16-22 tahun.

Mengacu pada pengertian pernikahan maka seseorang ketika menikah memiliki keinginan untuk hidup lebih baik lagi dalam hal kebahagiaan, perekonomian hingga mendapatkan keturunan. Pernikahan yang dilakukan oleh pasangan yang masih muda tentu perlu lebih banyak kesiapan baik mental maupun materi untuk bisa mencapai hal itu. Hal yang direncanakan untuk mencapai tujuan keharmonisan dan kebahagiaan tersebut tidak selalu berjalan sesuai apa yang diharapkan. Berdasarkan data perceraian yang terjadi di Indonesia mengindikasikan bahwa menikah tidak selalu bahagia, melainkan bisa saja berpisah ketika terjadi konflik. Kasubdit Kepenghuluan Direktorat Urais dan Binsyar Kementrian Agama mengatakan bahwa berdasarkan data sejak tahun 2009 hingga 2016 kenaikan angka perceraian mencapai 16-20 persen. Perceraian paling banyak terjadi pada tahun 2012 mencapai 372.557 kasus. Kasus perceraian tersebut dilakukan oleh pasangan yang berusia di bawah 35 tahun. Meningkatnya jumlah pernikahan muda selama sepuluh tahun terakhir berbanding lurus dengan meningkatnya angka perceraian (Gulalives, 2016). Di Bali, tepatnya di Kota Denpasar angka perceraian meningkat 10 persen setiap tahunnya (Republika, 2016). Kabupaten lain yang memiliki kasus perceraian pasangan muda yakni Karangasem. Terhitung sejak bulan Januari hingga April 2018 tercatat 50 kasus perceraian di Karangasem yang dilakukan oleh pasangan muda (BeritaBali, 2018).

Hasil penelitian dan pengembangan pada tahun 2016 menunjukkan bahwa perceraian di Indonesia baik pasangan muda maupun dewasa memiliki empat alasan utama antara lain, hubungan sudah tidak harmonis, tidak ada tanggung jawab khususnya terhadap anak, kehadiran pihak ketiga dan persoalan ekonomi. Menurut Kasdullah SH, MH, selaku Panitera Muda Hukum Pengadilan Agama IA Malang, lima faktor perceraian, yaitu faktor ekonomi, kekerasan dalam rumah tangga, ketidakharmonisan, pertengkaran terus menerus dan salah satu pihak memilih untuk pergi dari rumah (Gulalives, 2016).

Berdasarkan data tersebut, dapat diasumsikan bahwa ketidakharmonisan dalam pernikahan dapat disebabkan oleh 
ketidakserasian atau adanya ketidakcocokan satu sama lain. Perasaan tidak cocok atau tidak serasi merupakan salah satu indikasi dari ketidakpuasan pernikahan. Menurut Veroff (dalam Atwater, 1985) peningkatan kecenderungan adanya ketidakpuasan dalam pernikahan berdampak adanya perceraian. Hal tersebut menunjukkan bahwa betapa pentingnya kepuasan dalam pernikahan untuk menciptakan rumah tangga yang bahagia. Rumah tangga yang bahagia dapat membantu menjaga keutuhan hubungan pernikahan dan menjauhkan dari perceraian, maka dari itu kepuasan pernikahan menjadi penting untuk dimiliki oleh pasangan suami istri. Pernyataan tersebut didukung oleh hasil penelitian yang dilakukan oleh Permatasari (2014) bahwa kepuasan pernikahan akan sangat berpengaruh terhadap keutuhan rumah tangga.

Salah satu aspek yang dapat meningkatkan kepuasan dalam pernikahan yakni kecerdasan emosi. Mayer dan Salovey (1997) menjelaskan bahwa untuk menjalin hubungan dengan orang lain maupun pasangan hal yang sangat penting adalah kecerdasan emosi. Didukung dari hasil penelitian yang dilakukan oleh Fajarwati (2017) menyatakan bahwa kecerdasan emosi merupakan salah satu aspek yang memengaruhi kepuasan pernikahan serta untuk menjaga kelangsungan pernikahan di usia muda. Hasil penelitian yang dilakukan oleh Sari dan Widyastuti (2015) makin menguatkan bahwa kecerdasan emosi mampu mengurangi konflik dalam rumah tangga yang mampu meningkatkan kepuasan pernikahan. Kecerdasan emosi merupakan kemampuan individu dalam memotivasi diri dan bertahan menghadapi keadaan frustrasi, mengendalikan dorongan hati, mengatur suasana hati dan menjaga agar stressor tidak melumpuhkan kemampuan berpikir (Goleman, 2007). Sedangkan Mayer dan Salovey (1997) mendefinisikan kecerdasan emosi sebagai kemampuan untuk mengamati perasaan dan emosi diri sendiri dan orang lain, untuk membedakan dirinya dengan orang lain dan menggunakan informasi tersebut untuk mengarahkan pikiran dan tindakan seseorang. Mayer dan Salovey (dalam Mayer, Salovey, \& Caruso, 2004) menambahkan bahwa definisi dari kecerdasan emosi sebagai kemampuan untuk merasa secara akurat, menilai, dan mengekspresikan emosi, kemampuan untuk mengakses dan membangkitkan emosi agar membantu pikiran, kemampuan untuk memahami emosi dan pengetahuan terkait emosi, dan kemampuan meregulasi emosi untuk meningkatkan perkembangan emosi dan intelektual.

Berdasarkan pemaparan tersebut terlihat bahwa terdapat peran kecerdasan emosi terhadap kepuasan pernikahan. Untuk mengetahui apakah hal tersebut terjadi pada remaja yang menikah muda di Bali maka perlu adanya pembuktian lebih lanjut. Dengan demikian maka tujuan dari penelitian ini adalah untuk mengetahui bagaimana peran kecerdasan emosi terhadap kepuasan pernikahan pada remaja yang menikah muda di Bali serta seberapa besar kontribusi dari kecerdasan emosi terhadap kepuasan pernikahan.

\section{METODE PENELITIAN}

\section{Variabel dan Definisi Operasional}

Variabel bebas dalam penelitian ini adalah kecerdasan emosi. Variabel tergantung yang digunakan dalam penelitian ini adalah kepuasan pernikahan. Definisi operasional dari masing-masing variabel dalam penelitian ini adalah sebagai berikut:

Kepuasan pernikahan

Kepuasan penikahan adalah penilaian subjektif tentang kepuasan, kebahagiaan dan pengalaman yang menyenangkan yang dirasakan oleh suami maupun istri yang telah menikah mengenai pernikahan yang dijalani karena telah mencapai suatu tujuan. Semakin tinggi skor total yang diperoleh, maka semakin tinggi taraf kepuasan pernikahan.

$\underline{\text { Kecerdasan emosi }}$

Kecerdasan emosi adalah kemampuan untuk mengamati dan mengendalikan perasaan diri sendiri dan orang lain, serta menggunakan perasaan-perasaan itu untuk memandu pikiran dan tindakan. Semakin tinggi skor total yang diperoleh, maka semakin tinggi taraf kecerdasan emosi.

\section{Subjek}

Populasi pada penelitian ini adalah adalah remaja laki-laki serta perempuan yang menikah muda dan berada di Bali. Subjek dalam penelitian ini memiliki karakteristik sebagai berikut: Berjenis kelamin laki-laki dan perempuan, berusia 16-22 tahun, sudah menikah, dan berdomisili di Bali.

Teknik pengambilan sampel pada penelitian ini menggunakan teknik probability sampling dengan jenis cluster sampling. Cluster Sampling (Area Sampling) atau disebut juga cluster random sampling adalah teknik yang digunakan bilamana populasi terdiri dari kelompok-kelompok individu atau cluster (Sugiyono, 2016). Pada penelitian ini jumlah sampel minimum adalah sebanyak 66 orang, hal tersebut berdasarkan pada rumus untuk menentukan jumlah sampel minimum dilihat dari jumlah variabel bebas (VB) atau prediktornya yang disampaikan oleh Field (2009). Rumus tersebut yaitu $50+8$ x VB, sehingga diperoleh jumlah sampel minimum sebanyak 66 orang.

\section{Tempat dan Waktu Penelitian}

Berdasarkan hasil pengundian, daerah yang dijadikan sampel penelitian adalah Kota Denpasar, Kabupaten Gianyar, Kabupaten Bangli, Kabupaten Klungkung, Kabupaten Tabanan. Pengambilan data dilakukan menggunakan kuesioner yang disebar pertama kali dalam bentuk google form pada tanggal 25 April 2018. Kuesioner dalam bentuk hard copy dilaksanakan mulai dari 11 Mei 2018 sampai dengan 21 Mei 2018. Kuesioner yang disebar oleh peneliti terdiri dari informed concent, identitas diri, petunjuk pengisian, skala kepuasan pernikahan dan skala kecerdasan emosi. Total subjek pada google form berjumlah 42, dan hard copy berjumlah 40. Jumlah kuesioner gugur sebanyak 16 dikarenakan subjek yang mengisi tidak sesuai dengan kriteria yang telah ditetapkan. Total responden dalam penelitian ini sebanyak 66 subjek.

\section{Alat Ukur}

Terdapat dua skala yang digunakan dalam penelitian ini yaitu skala kepuasan pernikahan dan skala kecerdasan emosi. Kedua skala tersebut menggunakan jenis skala Likert yang terdiri dari empat pilihan jawaban, yaitu sangat sesuai (SS), sesuai (S), tidak sesuai (TS), dan sangat tidak sesuai (STS). Skala Likert digunakan untuk mengukur sikap, pendapat, dan persepsi seseorang atau kelompok orang tentang fenomena sosial (Sugiyono, 2016). Skala kepuasan pernikahan disusun berdasarkan teori dari Bradburry, Fincham, dan Beach (2000). 
Skala kecerdasan emosi disusun berdasarkan teori dari Mayer dan Salovey (dalam Salovey \& Grewal, 2005).

Menurut Azwar (2016) alat ukur yang valid dan reliabel adalah syarat untuk mampu memberikan informasi dan hasil data yang akurat. Pengukuran terhadap validitas isi dalam penelitian ini dapat dilakukan dengan teknik professional judgement yang dilakukan oleh dosen pembimbing agar aitem-aitem dalam alat ukur tersebut sesuai dengan blue print atau indikator perilaku yang hendak diukur. Proses pengujian validitas konstruk dilakukan dengan melakukan seleksi pada aitem-aitem skala berdasarkan korelasi aitem-total. Menurut Cronbach (dalam Azwar, 2016) koefisien korelasi aitem-total sama dengan atau lebih besar daripada 0.30 dianggap sudah memuaskan. Teknik pengukuran reliabilitas yang digunakan dalam penelitian ini adalah Cronbach Alpha. Reliabilitas skala dapat dikatakan baik apabila memiliki nilai koefisien alpha lebih besar dari 0.60 .

Hasil uji validitas skala kepuasan pernikahan memiliki koefisien korelasi aitem-total berkisar antara 0,382 sampai 0,772 . Hasil uji reliabilitas skala kepuasan pernikahan dengan menggunakan teknik Cronbach Alpha menunjukkan koefisian alpha $(\alpha)$ adalah 0,945 memiliki arti bahwa skala kepuasan pernikahan mampu mencerminkan 94,5\% variasi skor murni subjek. Hasil uji validitas skala kecerdasan emosi memiliki koefisien korelasi aitem-total berkisar antara 0,326 sampai 0,755 . Hasil uji reliabilitas skala kecerdasan emosi dengan menggunakan teknik Cronbach Alpha menunjukkan koefisian alpha $(\alpha)$ adalah 0,914 memiliki arti bahwa skala pola asuh autoritatif mampu mencerminkan $91,4 \%$ variasi skor murni subjek.

\section{Teknik Analisis Data}

Sebelum melakukan uji hipotesis data penelitian maka perlu dilakukan uji asumsi terlebih dahulu seperti uji normalitas dan uji linearitas. Uji normalitas data penelitian dilakukan dengan uji Kolmogorov-Smirnov. Uji linearitas data penelitian dilakukan dengan menggunakan test of linearity. Pengujian hipotesis penelitian dapat dilakukan setelah semua uji asumsi terpenuhi. Uji hipotesis pada penelitian ini menggunakan teknik uji regresi linear sederhana. Analisis data penelitian ini dilakukan dengan bantuan program IBM SPSS Statistics 23.0.0 for MAC OSX.

\section{HASIL PENELITIAN}

\section{Karakteristik Subjek}

Subjek dalam penelitian ini berjumlah 66 orang, terdiri dari 18 orang laki-laki dan 48 orang perempuan. Rentang usia subjek dalam penelitian ini adalah 16-22 tahun dengan mayoritas subjek berusia 22 tahun dengan persentase 43,93\%. Mayoritas pendidikan terakhir subjek pada penelitian ini adalah SMA dengan presentase sebesar 75,76\%. Mayoritas subjek berdomisili di Denpasar dengan persentase sebesar 48,49\%. Mayoritas subjek menikah diusia 20 tahun dengan persentase sebesar 31,81\%. Mayoritas subjek bekerja sebagai pegawai swasta dengan persentase sebesar 45,46\%.

\section{Deskripsi Data Penelitian}

Hasil deskripsi data penelitian yaitu kepuasan pernikahan dan kecerdasan emosi dapat dilihat pada tabel 1 (terlampir).

Hasil deskripsi pada tabel 1 menunjukkan bahwa variabel kepuasan pernikahan memiliki nilai mean empiris yang berbeda secara signifikan terhadap mean teoretisnya. Hal ini dapat dilihat dari nilai probabilitas uji one-sample $t$ test sebesar 0,000 yang lebih kecil dari taraf signifikansi yang digunakan yaitu 5\% atau $0,05(\mathrm{p}<\alpha)$. Nilai mean empiris yang lebih besar dari mean teoretis mengindikasikan bahwa subjek memiliki tingkat kepuasan pernikahan yang cenderung tinggi. Tabel 1 juga menunjukkan bahwa variabel kecerdasan emosi memiliki nilai mean empiris yang berbeda secara signifikan terhadap mean teoretisnya. Hal ini dapat dilihat dari nilai probabilitas uji onesample t test sebesar 0,000 yang lebih kecil dari taraf signifikansi yang digunakan yaitu $5 \%$ atau $0,05(\mathrm{p}<\alpha)$. Nilai mean empiris yang lebih besar dari mean teoretis mengindikasikan bahwa subjek memiliki tingkat kecerdasan emosi yang cenderung tinggi.

\section{Uji Asumsi}

\section{Uji Normalitas}

Uji normalitas dilakukan guna mengetahui sebaran skor variabel penelitian memiliki distribusi yang normal atau tidak. Uji normalitas dilakukan dengan menggunakan KolmogorovSmirnov. Apabila uji Kolmogorov-Smirnov menunjukkan probabilitas lebih besar daripada 0.05, maka data dikatakan berdistribusi secara normal. Sedangkan jika probabilitas data lebih kecil dari 0.05 , berarti data tidak berdistribusi normal (Sugiyono, 2016).

Berdasarkan hasil uji normalitas pada tabel 2 (terlampir) menunjukkan bahwa sebaran data pada variabel kepuasan pernikahan berdistribusi normal dengan nilai signifikansi 0,200 $(\mathrm{p}>0,05)$. Tabel 2 juga menunjukan bahwa sebaran data pada variabel pola kecerdasan emosi berdistribusi normal dengan nilai signifikansi 0,200 ( $\mathrm{p}>0,05)$.

Uji Linearitas

Uji linearitas dilakukan untuk mengetahui apakah terdapat hubungan yang linear antara kedua variabel penelitian, yaitu adanya hubungan antara skor variabel bebas dan tergantung yang menunjuk garis sejajar atau tidak. Uji linearitas dilakukan dengan menggunakan Test of Linearity pada program IBM SPSS Statistics 23.0.0 for MAC OSX. Hubungan kedua variabel dikatakan linear apabila nilai signifikansi pada Linearity lebih kecil dari 0,05 $(\mathrm{p}<0,05)$ dan Deviation from Linearity di atas 0,05 $(\mathrm{p}>0,05)$ (Priyanto, 2012).

Berdasarkan hasil uji linearitas pada tabel 3 (terlampir) menunjukkan bahwa nilai signifikansi linearity sebesar 0,000 $(p<0,05)$ dan signifikansi deviation from linearity sebesar 0,197 $(\mathrm{p}>0,05)$. Dengan demikian, maka terdapat hubungan linear secara signifikan antara variabel kecerdasan emosi dengan kepuasan pernikahan.

\section{Uji Hipotesis}

Uji hipotesis dilakukan untuk mengetahui jawaban sementara pada rumusan penelitian diterima atau ditolak. Uji hipotesis pada penelitian ini menggunakan analisis regresi linear sederhana dengan bantuan program IBM SPSS Statistics 23.0.0 for MAC 
OSX. Analisis ini bertujuan untuk mengetahui seberapa besar pengaruh variabel independen terhadap variabel dependen. Regresi digunakan untuk mengukur besarnya pengaruh variabel bebas terhadap variabel terikat dan memprediksi variabel terikat dengan menggunakan variabel bebas.

Berdasarkan hasil pada tabel 4 (terlampir) menunjukkan $\mathrm{F}$ hitung sebesar 53,780 dan signifikansi sebesar 0,000 $(\mathrm{p}<0,05)$. Dengan demikian, model regresi dalam penelitian ini layak digunakan atau dapat digunakan untuk memprediksi kepuasan pernikahan.

Berdasarkan tabel 5 (terlampir) diperoleh hasil kontribusi $\mathrm{R}$ Square yang didapatkan sebesar 0,457 atau $45,7 \%$ yang artinya kecerdasan emosi memengaruhi kepuasan pernikahan sebesar $45,7 \%$ sedangkan sisanya $54,3 \%$ kepuasan pernikahan dipengaruhi oleh faktor-faktor lain diluar variabel kecerdasan emosi yang tidak diteliti. Tabel di atas juga menampilkan nilai $\mathrm{R}$ yang merupakan simbol dari koefisien korelasi. Nilai R pada hasil uji menunjukkan angka 0,676 dimana nilai ini dapat diinterpretasikan bahwa hubungan kedua variabel penelitian ada di kategori kuat.

Berdasarkan hasil pada tabel 6 (terlampir) menginformasikan model persamaan regresi yang diperoleh dengan koefisien konstanta dan koefisien variabel pada kolom Unstandardized Coefficients B. Angka pada koefisien variabel menunjukkan positif yakni 1,353 yang memiliki arti bahwa variabel kecerdasan emosi memiliki hubungan yang positif terhadap variabel kepuasan pernikahan. Dijelaskan lebih lanjut bahwa apabila skor kecerdasan emosi meningkat maka akan meningkatkan pula skor kepuasan pernikahan begitupula sebaliknya. Diyakini hubungan antara variabel kecerdasan emosi dan kepuasan pernikahan merupakan hubungan yang fungsional atau dapat dikatakan kecerdasan emosi memengaruhi kepuasan pernikahan $(\mathrm{t}=7,334 ; \mathrm{p}=0,000)$ Prediksi taraf kepuasan pernikahan dari masing-masing subjek dengan persamaan regresi:

$\mathrm{Y}=12,354+1,353 \mathrm{X}$

Keterangan:

$\mathrm{Y}=$ Kepuasan Pernikahan

$\mathrm{X}=$ Kecerdasan Emosi

a. Konstanta sebesar 12,354 menyatakan bahwa jika tidak ada penambahan atau peningkatan skor pada kecerdasan emosi maka taraf kepuasan pernikahan sebesar 12,354 .

b. Koefisien regresi X sebesar 1,353 menyatakan bahwa setiap penambahan atau peningkatan satuan skor subjek pada variabel kecerdasan emosi, maka akan terjadi kenaikan taraf kepuasan pernikahan sebesar 1,353 .

\section{PEMBAHASAN DAN KESIMPULAN}

Hipotesis alternatif pada penelitian ini diterima berdasarkan nilai signifikansi 0,000. Hasil dari penelitian ini adalah kecerdasan emosi memiliki peran dalam kepuasan pernikahan pada remaja yang menikah muda di Bali. Dikarenakan hasil koefisien pada uji hipotesis bernilai positif maka individu yang memiliki tingkat kecerdasan emosi yang tinggi akan merasakan kepuasan pernikahan yang tinggi, dan begitu pula sebaliknya. Individu yang memiliki tingkat kecerdasan emosi yang tergolong rendah memiliki tingkat kepuasan pernikahan yang lebih rendah. Nilai $\mathrm{R}$ square pada hasil regresi sebesar 0,457 sehingga dapat diartikan bahwa kecerdasan emosi menentukan $45,7 \%$ taraf kepuasan pernikahan sedangkan $54,3 \%$ taraf kepuasan pernikahan ditentukan oleh variabel lain yang tidak diteliti.

Hasil penelitian ini sejalan dengan penelitian sebelumnya yang dilakukan oleh Nurhayati (2011) yaitu kecerdasan emosi memengaruhi kepuasan pernikahan. Hasil penelitian lainnya yakni penelitian Novirayanthi (2017) yang menunjukkan bahwa terdapat hubungan positif antara kecerdasan emosi dan kepuasan pernikahan. Kedua penelitian tersebut semakin menguatkan bahwa kecerdasan emosi memiliki peran di dalam kepuasan pernikahan. Arah hubungan kedua variabel pada penelitian ini menunjukkan arah positif. Arah hubungan atau pengaruh yang positif berarti apabila variabel kecerdasan emosi meningkat maka akan menyebabkan peningkatan pada variabel kepuasan pernikahan.

Fenomena pernikahan di usia remaja belakangan ini semakin banyak terjadi di Bali. Jika dilihat dari tahap perkembangannya maka seharusnya masa remaja belum tepat ketika memutuskan untuk menikah dikarenakan menikah merupakan tugas dalam tahap perkembangan dewasa. Sesuai dengan apa yang dikemukakan oleh Hurlock (2000) bahwa tugas-tugas perkembangan masa dewasa awal yakni memilih teman (sebagai calon istri atau suami), belajar hidup bersama dengan suami/istri, mulai hidup dalam keluarga atau hidup berkeluarga, mengelola rumah tangga. Sedangkan tahapan perkembangan remaja seharusnya hanya pada sampai pencarian jati diri dan juga mencari teman sebaya bukan untuk membina rumah tangga. Namun sesuai dengan yang dikemukakan oleh Hurlock (2000) bahwa masa remaja mengakibatkan individu merasa berada pada tingkat yang sama dengan orang yang lebih tua maka banyak remaja yang mengambil tugas perkembangan dewasa awal yakni menikah.

Mayer dan Salovey (1997) menjelaskan bahwa menjalin hubungan dengan orang lain maka hal yang sangat dibutuhkan adalah kecerdasan emosi. Sesuai dengan hasil penelitian Fajarwati (2017) bahwa kecerdasan emosi merupakan salah satu aspek yang berperan dalam kepuasan pernikahan serta untuk menjalin kelangsungan pernikahan di usia muda. Kemampuan dalam mengatur dan meregulasi emosi pada diri sendiri membantu individu untuk lebih memahami dan menghargai perasaan pasangan dan anggota keluarga (Lavalekar, Kulkarni \& Jagtap, 2010). Hal itu sesuai dengan apa yang dikemukakan oleh Shackelford dan Buss (2000) yaitu di dalam pernikahan, pasangan penting untuk memiliki kemampuan mengatur emosi karena kestabilan emosi adalah prediktor yang paling konsisten memengaruhi kepuasan pernikahan. Laki-laki atau perempuan yang menikah dengan orang yang memiliki kepribadian seperti stabilitas emosi yang rendah, kurang teliti dan kurang terbuka sering mengeluh bahwa pasangannya memiliki sifat cemburu berlebih, posesif, dan egosentris yang berdampak pada menurunnya tingkat kepuasan pernikahan. Pendapat tersebut didukung oleh pernyataan bahwa salah satu cara untuk 
meningkatkan kepuasan dalam pernikahan adalah dengan meningkatkan kecerdasan emosi (Weisinger, 2006).

Menurut Goleman (2007) pasangan dapat mengelola kemarahan dan kecemasan akan lebih menguntungkan dan menghasilkan kepuasan dalam pernikahan dibandingkan pasangan yang tidak dapat mengelola kemarahan, kecemasan, dan menghindari depresi. Hasil penelitian ini menunjukkan kecerdasan emosi pada remaja yang menikah muda di Bali berada pada rentang sedang sampai tinggi. Dalam penelitian ini mayoritas subjek memiliki taraf kecerdasan emosi yang tinggi.

Taraf kecerdasan emosi pada subjek penelitian ini bisa tergolong tinggi disebabkan oleh beberapa faktor. Salah satunya adalah faktor tingkat pendidikan, dimana rata-rata subjek telah menyelesaikan tingkat pendidikan di jenjang SMA/SMK/SLTA. Hal ini diperkuat oleh hasil penelitian Muhaimin (2008) bahwa kecerdasan emosi seseorang akan meningkat sesuai dengan lamanya waktu yang dihabiskan dalam menempuh pendidikan. Pendidikan bukan semata-mata sebagai sarana untuk persiapan kehidupan yang akan datang, tetapi untuk kehidupan sekarang yang sedang mengalami perkembangan menuju tingkat kedewasaannya (Fuad, 2003). Kehidupan pendidikan merupakan pengalaman proses belajar yang dihayati sepanjang hidupnya, baik di dalam jalur pendidikan sekolah maupun luar sekolah (Sunarto \& Hartono, 2002).

Taraf kecerdasan emosi remaja yang termasuk dalam kategori tinggi dalam penelitian ini menggambarkan bahwa subjek dalam penelitian ini yaitu remaja yang menikah muda di Bali telah mampu untuk mengamati dan mengendalikan perasaan diri sendiri dan orang lain, serta menggunakan perasaan-perasaan itu untuk memandu pikiran dan tindakannya. Hal ini akan berbanding terbalik jika seseorang memiliki kecerdasan emosi yang rendah. Taraf kecerdasan emosi yang tergolong tinggi akan memengaruhi peningkatan pada taraf kepuasan pernikahan. Terbukti dengan hasil penelitian yang menyatakan bahwa tingkat kepuasan pernikahan remaja termasuk ke dalam kategori yang sangat tinggi.

Tingkat kepuasan pernikahan yang sangat tinggi dalam hasil penelitian ini mengartikan bahwa subjek yakni remaja yang menikah muda di Bali memiliki penilaian subjektif yang positif terhadap pernikahannya dikarenakan tujuannya telah tercapai. Tingginya taraf kepuasan pernikahan pada penelitian ini sesuai dengan hasil penelitian sebelumnya yang dilakukan oleh Wardhani (2015) dimana kepuasan pernikahan tergolong sangat tinggi dialami oleh perempuan yang menikah dini yang produktif bekerja dibandingkan dengan individu yang menikah muda namun tidak bekerja. Pada hasil penelitian ini menunjukkan bahwa kecerdasan emosi memengaruhi 45,7\% dalam kepuasan pernikahan. Di mana faktor lainnya sebanyak 54,3\% disebabkan oleh beberapa faktor.

Duvall dan Miller (1985) mengatakan terdapat dua faktor yakni faktor masa lalu dan masa kini. Faktor masa lalu yakni kebahagiaan dalam pernikahan orangtua, disiplin, kedekatan, adanya pendidikan seks yang memadai dari orangtua, masa kanak-kanak, pendidikan dan pergaulan. Faktor masa kini yakni kehidupan seksual, kepuasan terhadap tempat tinggal, pendapatan keluarga, tingkat kesetaraan, komunikasi, kehidupan sosial, ekspresi kasih sayang/afeksi dan kepercayaan. Sedangkan menurut Hurlock (1997) terdapat empat hal yang memengaruhi kepuasan pernikahan yaitu penyesuaian sosial terhadap pasangan, penyesuaian seksual, penyesuaian keuangan dan penyesuaian terhadap keluarga besar pasangan.

Maka simpulan dari pemaparan di atas bahwa hubungan antara variabel kecerdasan emosi dan kepuasan pernikahan merupakan hubungan yang fungsional atau dapat dikatakan kecerdasan emosi memiliki peran dalam kepuasan pernikahan pada remaja yang menikah muda di Bali.

Pada penelitian ini masih memiliki beberapa keterbatasan yaitu, beberapa data lain mengenai demografi subjek terlewat saat pengambilan data, yang sebenarnya akan mampu mengungkap lebih banyak faktor yang mengakibatkan kepuasan pernikahan. Keterbatasan lainnya yakni peneliti kesulitan mencari referensi yang tepat dan terbaru untuk penelitian ini.

\section{Kesimpulan}

Berdasarkan hasil analisis penelitian yang telah dijabarkan, maka kesimpulan dari penelitian ini adalah pertama, hubungan antara variabel kecerdasan emosi dan kepuasan pernikahan merupakan hubungan yang fungsional atau dapat dikatakan kecerdasan emosi memiliki peran terhadap kepuasan pernikahan pada remaja yang menikah muda di Bali. Kedua, remaja yang menikah muda di Bali mayoritas memiliki kecerdasan emosi dalam kategori tinggi yang memiliki arti bahwa remaja yang menikah muda di Bali mampu untuk mengamati dan mengendalikan perasaan diri sendiri dan orang lain, serta menggunakan perasaan-perasaan itu untuk memandu pikiran dan tindakannya. Ketiga, remaja yang menikah muda di Bali mayoritas memiliki kepuasan pernikahan dalam kategori sangat tinggi, yang memiliki arti bahwa remaja yang menikah muda di Bali memiliki penilaian subjektif yang positif terhadap pernikahannya dikarenakan tujuannya telah tercapai.

\section{Saran}

Berdasarkan kesimpulan diatas, maka saran yang dapat diberikan kepada pihak-pihak terkait adalah sebagai berikut:

Bagi remaja

Bagi remaja yang menikah diusia muda, akan mampu menghasilkan tingkat kepuasan pernikahan yang tinggi dengan catatan memiliki tingkat kecerdasan emosi tinggi, cara yang dapat dilakukan yakni dengan mengasahnya seperti mengikuti pelatihan. Bagi remaja yang ingin menikah di usia muda diharapkan mampu mempersiapkan diri terutama kecerdasan emosi yang menjadi aspek kepuasan pernikahan pada penelitian ini, hal itu dapat dilakukan mulai dengan mengenali keadaan emosi di dalam dirinya.

Bagi orang tua

Para orangtua disarankan agar memberikan motivasi, penerapan dan pemahaman positif agar anak-anak di usia remaja lebih memahami hubungan kecerdasan emosional dalam menjalankan semua hal dalam hidupnya semenjak dini terutama bagi yang ingin atau sudah menikah di usia muda.

\section{Bagi masyarakat}

Dari hasil penelitian ini masyarakat diharapkan mampu untuk menyebarkan informasi bahwa menikah di usia muda bisa 
mengalami tingkat kepuasan pernikahan yang tinggi jika individu tersebut mampu mengenali emosi di dalam dirinya dan orang lain serta mampu menggunakan emosi pada situasi yang tepat. Maka dari itu, masyarakat diharapkan mampu menyebarkan informasi terkait pentingnya kecerdasan emosi di dalam kehidupan sehari-hari.

Bagi pemerintah

Hasil penelitian ini dapat digunakan sebagai bahan pertimbangan bagi pemerintah dalam membuat program yang dapat meningkatkan kecerdasan emosi remaja.

Bagi penelitian selanjutnya

Bagi penelitian selanjutnya yang ingin melakukan penelitian mengenai peran kecerdasan emosi terhadap kepuasan pernikahan dapat memodifikasi skala yang digunakan pada penelitian ini sesuai dengan tujuan penelitian yang akan dilakukan. Dikarenakan pada penelitian ini terdapat kekurangan data demografi, maka bagi peneliti selanjutnya diharapkan mampu melengkapi data demografi dan juga dapat mencari variabel bebas lain seperti tingkat pendidikan atau kemampuan beradaptasi agar data yang dihasilkan lebih akurat dan komprehensif mengenai faktor yang menyebabkan terjadinya kepuasan pernikahan.

\section{DAFTAR PUSTAKA}

Atwater, E. (1985). Psychology Adjusment ( $\left.7^{\text {th }} e d\right)$. New Jersey : Prentice Hall, Inc.

Azwar, S. (2016). Sikap Manusia Edisi ke-2. Yogyakarta: Pustaka Pelajar.

Azwar, S. (2016). Penyusunan Skala Psikologi Edisi 2. Yogyakarta: Pustaka Belajar.

Azwar, S. (2016), Reliabilitas dan validitas, edisi 4. Yogyakarta: Pustaka pelajar.

Bachtiar, A. (2004). Menikahlah, Maka Engkau Akan Bahagia!. Yogyakarta: Saujana.

Badan Pusat Statistik. (2016). Kemajuan yang Tertunda: Analisis Data Perkawinan Usia Anak di Indonesia, Berdasarkan Hasil Susenas 2008-2012 dan Sensus Penduduk 2010. JakartaIndonesia: Badan Pusat Statistik.

Badan Pusat Statistik Jakarta Pusat. (2016). Pendataan Sosial Ekonomi Tahun 2008-2012. Jakarta Pusat: Badan Pusat Statistik.

Balipost. (2012). Di Gianyar, Bangli dan jembrana Dominan karena Hamil. Diakses dari https://www.facebook.com/balipost/posts/31350794538252 0

BeritaBali. (2018). 75\% Kasus Perceraian di Karangasem Disebabkan Media Sosial. Diakses dari https://www.beritabali.com/read/2018/04/13

Bradburry, T. N., Fincham, F. D., \& Beach, S. R. (2000). Research on the nature and determinants of marital satisfaction: a decade in review. Journal of Marriage and The Family, 62, 964$980 . \quad$ Diakses dari https://www.academia.edu/1507273/Research_On_The_Na ture_And_Determinants_Of_Marital_Satisfaction_A_Deca de In Review

Duvall, E. M. \& Miller, B.C. (1985). Marriage and family development $\left(9^{\text {th }}\right.$ ed.). New York: Harper \& Row Publishers

Fajarwati, W. (2017). Hubungan kecerdasan emosi dengan kebahagiaan pernikahan pada istri yang bekerja. Jurnal psikoborneo, 5 (2), 406-413

Field, A. (2009). Discovering Statistics using SPSS Third Edition. London: Sage Publications.

Fuad, H. (2003). Dasar-dasar Kependidikan. Jakarta: Rineka Cipta Goleman, D. (2007). Kecerdasan emosional. Jakarta: Gramedia
Pustaka Utama.

Gulalives. (2016). Tingkat Perceraian di Indonesia Termasuk yang Tertinggi di Dunia. Diakses dari http://www.gulalives.co/2016/09/26/tingkat-perceraian-diindonesia-termasuk-yang-tertinggi-di-dunia/

Hurlock, Elizabeth B. (1997). Psikologi Perkembangan Suatu Pendekatan Sepanjang Rentang Kehidupan. Terjemahan (edisi kelima). Jakarta: Erlangga

Hurlock, Elizabeth, B. (2000). Psikologi Perkembangan. Jakarta: Erlangga.

Lavalekar, A., Kulkarni, P., \& Jagtap, P. (2010). Emotional in and marital satisfaction. Journal of Psychological Research, 5(2), $185-194$ Diakses dari https://www.researchgate.net/.../283886890

Mayer, J, D. \& Salovey, P. (1997). What is Emotional Intelligence? In Salovey, P., \& Sluyter, D. J. Emotional Development and Emotional Intelligence: Educational Implications. New York: Harper Collins.

Mayer, J. D., Salovey, P., \& Caruso, D. R. (2004). Theory, findings, and implications. Psychological Inquiry, 15(3), 197-215. Diakses dari http://psycnet.apa.org/record/2004-18872-002

Muhaimin. (2008). Pengaruh Pendidikan Tinggi Akuntansi Terhadap Kecerdasan Emosional Mahasiswa Di Eks Karesidenan Pekalongan. Jurnal Ekonomi dan Kewirausahaan, 8(1), 5168. Diakses dari https://www.ejurnal.com/2013/12/pengaruh-pendidikan-tinggiakuntansi.html

Novirayanthi, I. A. I. (2017). Hubungan antara Kecerdasan Emosi dengan Kepuasan Perkawinan. Skripsi. Universitas Sanata Dharma. Diakses dari http://repository.usd.ac.id/eprint/11508

Nurhayati. (2011). Kecerdasan Emosi dan Kepuasan Pernikahan pada Istri TNI di Makassar. Skripsi. Universitas Negeri Makassar. Diakses dari http://eprints.unm.ac.id/436/1/Nurhayati.docx.

Otonomi. (2016). Sejumlah Siswa di Tabanan Putus Sekolah Karena Nikah Muda. Diakses dari https://www.otonomi.co.id/news/puluhan-siswa-ditabanan-putus-sekolah--161102u.hl

Papalia, E. D. (2009). Human Development : Perkembangan Manusia. Jakarta: Salemba Humanika

Permatasari, Y. (2014). Perbedaan Kepuasan Pernikahan Pada Istri Yang menikah di Usia Remaja dan Dewasa. Skripsi. Universitas Kristen Satya Wangsa. Diakses dari https://www.repository.uksw.edu/bitstream/123456789/894 9/1/T1 802009042 Full\%20text.pdf

Republika. (2016). Kasus Perceraian di Denpasar Meningkat. Diakses dari https://www.republika.co.id/o5jrld384

Salovey, P., Grewal, D. (2005). The science of emotional intelligence. Current Direction in Psychological Science, 14(6), 281-285. Diakses dari http://ei.yale.edu/publication/the-science-ofemotional-intelligence/

Santrock, J.W. (2007). Psikologi Perkembanga Edisi 11 Jilid 1. Jakarta: Erlangga

Sari, T.D. \& Widyastuti, A. (2015). Hubungan Antara Kecerdasan Emosi dengan Kemampuan Manajemen Konflik Pada Istri. Jurnal Psikologi, 11(1), 49-54. Diakses dari http://ejournal.uinsuska.ac.id/index.php/psikologi/article/view/1433

Shackelford, T. K. \& Buss, D. M. (2000). Marital satisfaction and spousal cost- infliction. Personality and Individual Differences, 28, 917-928. Diakses dari https://www.sciencedirect.com/science/article/pii/S019188 6999001506

Sugiyono. (2016). Metode Penelitian Kombinasi (Mixed Methods) . Bandung : Alfabeta

Sunarto \& Hartono. (2002). Perkembangan Peserta Didik. Jakarta: RINEKA CIPTA 
Survei Sosial dan Ekonomi Nasional (Susenas). (2012). Jakarta

Undang-Undang Republik Indonesia Tentang Perkawinan. UU No.1 Tahun 1974

Undang-Undang Republik Indonesia Tentang Perlindungan Anak. UU No. 23 Tahun 2002

Wardhani,B.S.R.(2015). Perbedaan Kepuasan Pernikahan Pada Wanita Bekerja dan Tidak Bekerja. Skripsi. Fakultas Psikologi Universitas Kristen Satya Wacana. Diakses dari http:// repository. uksw. edu/ bitstream/ 123456789/ 8985/2/ T1_802009132_Full\%20text.pdf

Walgito, B. (2002). Bimbingan \& Konseling Perkawinan. Yogyakarta: ANDI OFFSET

Weisinger, H. (2006). Emotional Intelligence at Work: Pemandu Pikiran dan Perilaku Anda Untuk Meraih Kesuksesan. Jakarta: PT Bhuana Ilmu Populer. 


\section{LAMPIRAN}

Tabel 1

Deskripsi Data Penelitian

\begin{tabular}{|c|c|c|c|c|c|c|c|c|}
\hline Variabel & $\mathrm{N}$ & $\begin{array}{c}\text { Mean } \\
\text { Teoreti } \\
\text { s }\end{array}$ & $\begin{array}{c}\text { Mean } \\
\text { Empiris }\end{array}$ & $\begin{array}{l}\text { Standar } \\
\text { Deviasi } \\
\text { Teoretis }\end{array}$ & $\begin{array}{l}\text { Standar } \\
\text { Deviasi } \\
\text { Empiris }\end{array}$ & $\begin{array}{l}\text { Sebaran } \\
\text { Teoretis }\end{array}$ & $\begin{array}{l}\text { Sebaran } \\
\text { Empiris }\end{array}$ & $\mathrm{t}$ \\
\hline $\begin{array}{c}\text { Kepuasan } \\
\text { Pernikahan }\end{array}$ & 66 & 92,5 & 115,20 & 18,5 & 15,809 & $37-148$ & $69-145$ & $\begin{array}{c}11,664 \\
p= \\
(0,000)\end{array}$ \\
\hline $\begin{array}{c}\text { Kecerdasan } \\
\text { emosi }\end{array}$ & 66 & 67,5 & 76,03 & 13,5 & 7,897 & $27-108$ & $63-93$ & $\begin{array}{c}8,775 \\
p= \\
(0,000)\end{array}$ \\
\hline
\end{tabular}

Tabel 2

Uji Normalitas Data Penelitian

\begin{tabular}{lccc}
\hline \multicolumn{1}{c}{ Variabel } & $\begin{array}{c}\text { Kolmogorov- } \\
\text { smirnov }\end{array}$ & $\begin{array}{c}\text { Asymp. Sig (2- } \\
\text { tailed) }\end{array}$ & Hasil Uji \\
\hline Kepuasan Pernikahan & & 0,200 & Normal \\
Kecerdasan Emosi & & 0,200 & Normal \\
\hline
\end{tabular}

Tabel 3

Uji Linearitas Data Penelitian

\begin{tabular}{ccccc}
\hline & & & F & Sig. \\
\hline Kepuasan & Between & Linearity & 60,801 & 0,000 \\
Permikahan*Kecerdasan & Groups & & & \\
Emosi & & Deviation from & 1,348 & 0,197 \\
& & Linearity
\end{tabular}

Tabel 4

Hasil Signifikansi Uji Regresi Linear Sederhana

\begin{tabular}{|c|c|c|c|c|c|c|}
\hline \multicolumn{7}{|c|}{ ANOVA } \\
\hline & & Sum of & & & & \\
\hline \multicolumn{2}{|l|}{ Model } & Squares & Df & Mean Square & F & Sig. \\
\hline \multirow[t]{3}{*}{$\overline{1}$} & Regression & 7417.461 & 1 & 7417.461 & 53.780 & $.000^{b}$ \\
\hline & Residual & 8826.979 & 64 & 137.922 & & \\
\hline & Total & 16244.439 & 65 & & & \\
\hline
\end{tabular}

Tabel 5

Besar Pengaruh Variabel Bebas terhadap Variabel Tergantung

\begin{tabular}{ccccc}
\hline Model & $\mathbf{R}$ & R Square & $\begin{array}{c}\text { Adjusted } \mathbf{R} \\
\text { Square }\end{array}$ & $\begin{array}{c}\text { Standard Error } \\
\text { of the Estimate }\end{array}$ \\
\hline 1 & 0.676 & 0.457 & 0.448 & 11.744
\end{tabular}


Tabel 6

Garis Regresi Linear Sederhana

\begin{tabular}{lccccc}
\hline & & Unstandardized Coefficients & $\begin{array}{c}\text { Standardized } \\
\text { Coefficients }\end{array}$ & t & Sig. \\
\cline { 2 - 4 } & $\mathbf{B}$ & Std. Error & Beta & & \\
\hline (Constant) & 12.354 & 14.098 & & 0.876 & 0.384 \\
Kecerdasan & 1.353 & 0.184 & 0.676 & 7.334 & 0.000 \\
Emosi & & & & & \\
\hline
\end{tabular}

